\title{
The Implementation of Empowerment Program for Remote Indigenous Community in Maudemu Village, Lamaknen Subdistrict, Belu District
}

\author{
(1) Yerimias Leli, (2) Lenny Tamunu, (3) J. L. Rupidara \\ Graduate Program of Administrative Studies, Graduate Program, Universitas Nusa Cendana Kupang, Nusa \\ Tenggara Timur, Indonesia
}

\begin{abstract}
This research described the Implementation of Remote Indigenous Community Empowerment Program Policy in Maudemu Village, Lamaknen Subdistrict, Belu District. This qualitative research focused on investigating the; (1) Standards and policy objectives, (2) Implementation resources, (3) Communication between organizations and program enhancement, (4) Characteristics of the implementing agencies, (5) Disposition of implementers, (6) Environmental social, economic and political conditions. This research was conducted in Maudemu Village, Lamaknen Subdistrict, Belu District which location was selected using a purposive technique (based on certain considerations). Research data were in the forms of primary and secondary data collected through interviews, documentation and observation. The data were obtained from various data sources including from people, documents and events. The obtained data were then analyzed using a data analysis technique proposed by Bogdan \& Biklen (in Moleong, 2001: 9).

The results of this research showed that; (1) the main problems experienced by RIC residents in Maudemu Village, Belu Regency, East Nusa Tenggara were; (a) Limitations in meeting basic needs, including clothing, food and shelter; (b) Limitations in accessing various services provided by the government, including education, health, public administration, religious facilities and clean water services; (c) Inadequate mother and children welfare. (2) The implementation of the Empowerment Program for Remote Indigenous Community in the Maudemu village of Lamaknen sub-district could not meet the predetermined qualifications. However, some actions carried out have been appropriate to bring better changes, especially in improving the life and welfare of the remote indigenous communities.
\end{abstract}

Key Words: Implementation, Policy, Program, Empowerment, Village, Indigenous

DOI: $10.7176 /$ PPAR/9-12-09

Publication date: December $31^{\text {st }} 2019$

\section{BACKGROUND}

The communities in East Nusa Tenggara are classified as Remote Indigenous Communities category, in which 57,659 were spread in 22 districts / cities. Those communities need serious attention from the government and stakeholders. Only 6,968 have been properly taken care. Meanwhile, the rest have better conditions than those of the very poor category, yet they are still considered poor as they did not have sufficient income to prevent them from experiencing deficiencies or helpless conditions (https://bappeda.nttprov.go.id $>$ categor). Unfortunately, some communities gave negative responses toward new ideologies and technologies introduced to them because they did not have sufficient social security to deal with the risk of failure.

Based on data from the Governance Bureau, East Nusa Tenggara Province consists of 556 large and small islands, 42 of which have been inhabited while the rest 524 islands are uninhabited and 42 islands have not yet been named. On 42 named islands, poor residents live including those belonging to remote indigenous communities. There were approximately 54,674 families categorized as Remote Indigenous Communities (RIC) in East Nusa Tenggara living in 22 Regencies / Cities, 44 Districts and 440. To address problems related to Remote Indigenous Communities (RIC) in East Nusa Tenggara, since 2007 the provincial government has collaborated with the district government and Nusa Cendana University to identify, establish and coordinate with the central government to find proper solutions. The collaboration resulted in an empowerment program which implementation has covered 7,075 families (Report on the implementation of RIC Empowerment in NTT Province).

The Department of Social Affairs of East Nusa Tenggara Province as the one that implemented the development program for Social Welfare along with the provincial government started to implement the Empowerment Program for Remote Indigenous Community in the region by establishing SK LWG Number 197 of 2014 concerning Working Clusters (POKJA) to handle the Remote Indigenous Community Empowerment Program by collaborating with related institutions. The implementation of this program is under the authority of the provincial government. To implement the program, PRIC LWGs were established based on Regent's Decree who holds the regional autonomy, by building a synergy between SKPDs who were expected to play active roles in the implementation of the Remote Indigenous Community Empowerment Program (hereinafter abbreviated as 
RIC). Meanwhile, addressing social issues is under the authority of the Regency / City government. However, the city government should collaborate with the provincial government, central government and competent agencies in the district to support the program implementation in the district area. It is expected that the distribution of authority is given to the lowest unit of government, namely the Village Government in order to implement the principles of democracy in which actions should be done from, by and for these poor families.

This research was carried out to find out and describe the Implementation of Empowerment Program for Remote Indigenous Community in Maudemu Village, Lamaknen District, Belu Regency. This research proposed both practical benefits and theoretical benefits. The practical benefits include; (1) The results of this research are expected to be useful as a reference for the government in identifying determinants of the empowerment program in Maudemu Village, Lamaknen District, Belu Regency. (2) As a guideline for people who participate in the development process, especially in the implementation of RIC empowerment policies to enhance the synergy between the agencies related to the community for more effective and efficient development. (3) As insights for other researchers who might be interested in conducting further research. Furthermore, the intended academic benefits are; (1) In regards to the conceptual framework reference, the theory of public policy implementation should support the implementation of the empowerment programs for remote indigenous communities in Maudemu Village, Lamaknen District, Belu Regency, NTT. (2) The results of this study are expected to broaden up the understanding and mindset as well as expand scientific treasures regarding the implementation of RIC empowerment program policies.

\section{The Concept of Public Policy \\ The Definition of Public Policy}

The term policy in scientific studies has been put forward by many experts from various disciplines. Broadly speaking, some experts have slightly different definition of public policy. Lasswell (1970) defined policy as; "A projected program of goals values and practices (a program to achieve goals, values and directed practices). Whilst, Anderson (2003) mentioned that policy is an action toward certain goal done by a person or a number of actors to certain solve a problem. Titmuss (1974) added that policy refers to the principles of governing actions directed at certain goals that is always problem-oriented and action-oriented.

The terms "policy" and "public" in Public Policy have been defined in some literatures. Various definitions of public policy were proposed by experts, including by Eyestone (1971) who defined public policy as "The relationship between government units and their environment". Unfortunately, this definition is still considered too broad to be understood and it brings uncertain meanings. The definition can cover almost all elements in the context of a nation.

Heinz Eulau and Prewitt (1973: 265) defined public policy as a permanent decision characterized by consistency and repetition (repetition) of the behavior of those who make and of those who comply with the decision. Rose (1969) also stated that public policy is "a long series of many or a few interconnected activities that bring consequences for those concerned as different decisions". Rose gave a useful note that policy is part of a mosaic or pattern of activities instead of merely a regulatory pattern.

\section{The Process of Public Policy}

Anderson (1979: 23-24) as a public policy expert determined public policy process as follows; (1) Problem formulation; (2) What is the problem? What made the matter a matter in government's agenda ?; (3) Policy formulation; (4) How to develop options or alternatives to solve the problem? Who participated in the policy formulation ?; (5) Policy adoption: how are alternatives determined? What kind of requirements / criteria that must be met? Who will carry out the policy? What is the process or strategy for implementing the policy? What is the content of the policies?; (6) Implementation: who is involved in the policy implementation? What are they working on? What is the impact of the contents?; (7) Evaluation: how is the success rate or impact of the policy? Who evaluates the policy? What are the consequences of policy evaluation? Are there demands to make changes or cancellations?

Whereas Ripley (1985: 49) mentioned the stages or processes of public policy beginning with the preparation of the agenda, formulation and legitimacy of policies, implementation of policies, evaluation of implementation, and performance of impacts and new policies which process is illustrated in the following figure: 


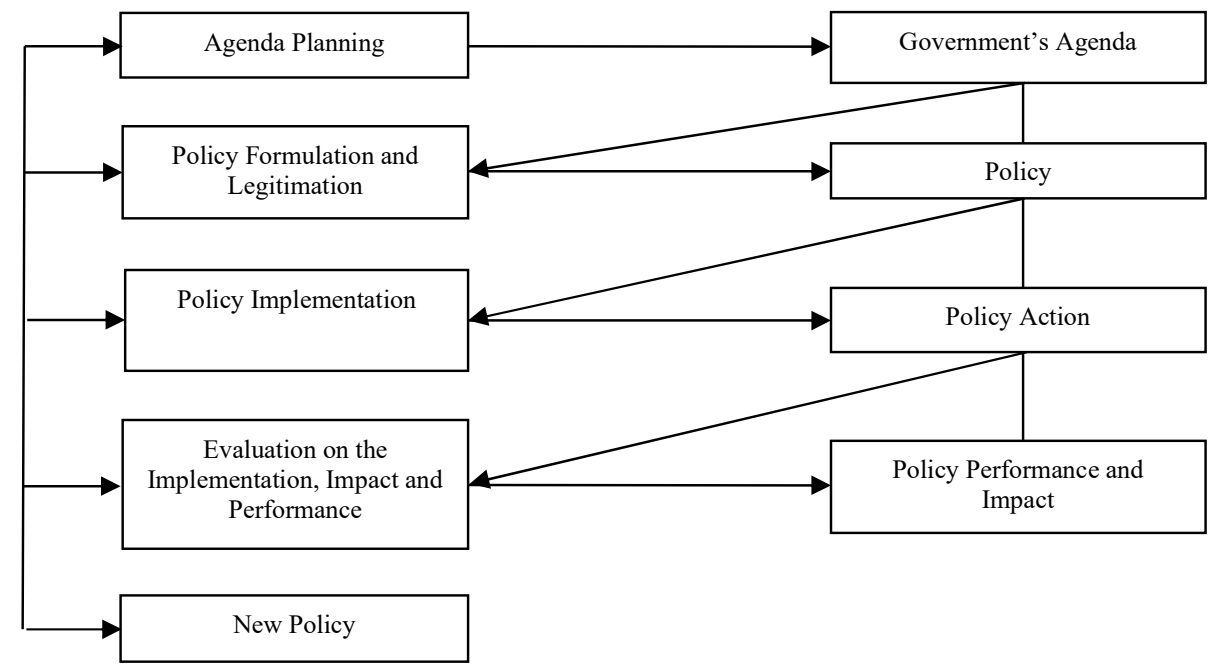

\section{The Concept of Policy Implementation \\ The Definition of Policy Implementation}

Figure 1. The Process of Public Policy

The term implementation has been described by Edward (1980) as a part of policy making process, where after one of the policies is established and legal legitimacy is obtained, the policy will be applied to influence the community. This view was also proposed by Pressman and Wildavsky (1973) who suggested that implementation is the process of interaction between goal setting and the ability to connect actions in a causal chain to achieve the intended results and outcomes.

Van Meter and Van Horn (in Nawawi, 2009; 131) defined policy implementation as an action taken either by individuals or government officials or private groups to achieve certain objectives outlined in the policy decision. Mazamnian and Paul Sabatier (1983: 61) believe that policy implementation refers to the implementation of basic policy decisions, usually in the form of laws, but it can also appear in the form of orders or important executive decisions or decisions made by Research Agency.

\section{Factors Affecting Policy Implementation}

Edward III (in Subarsono, 2005) put forward two premises for the purpose of the study related to policy implementation, namely the preconditions are needed for successful policy implementation and the obstacles that might occur in its application. To answer those questions, factors influencing the implementation of a policy are identified as independent variables that affect the performance of the implementation. These factors include four variables, namely: (1) Communication; (2) Resources; (3). Disposition; and (4) bureaucratic structure. These four factors do not only have direct influence, but they also have indirect influence toward each other.

Regarding various views proposed by experts, it can be seen that experts have a variety of views in determining factors that influence policy implementation. In this case, the researcher was interested in investigating the view proposed by Meter and Horn (in Subarsono, 2005) which mentioned six variables influencing policy implementation, namely: (1) Standards and policy objectives. Policy standards and objectives according to these two experts must be clear and measurable to make them possible to realize. If the standards and policy objectives are unclear, there will be multiple interpretations that might trigger conflicts between agencies; (2) Resources. Policy implementation requires resources including human resources and non-human resources; (3) Relationship between organizations. Some programs need adequate support and coordination with other agencies to achieve the predetermined goals; (4) Characteristics of the agencies, which include bureaucratic structures, norms and patterns of relationships within the bureaucracy, all of which known as factors affecting the implementation of a policy; (5) Socio-political and economic conditions that include economic resources environment policy implementation, the extent to which interest groups provide support for policy implementation, the public opinion and whether the political elite supports the implementation of policies; (6) Disposition of the implementer which includes three important aspects including (a) The implementer's response to the policy will affect the willingness to implement the policy; (b) Cognition, i.e. comprehension about the policy; and (c) The intensity of the implementer's disposition.

In short, Meter and Horn's view (in Subarsono, 2005) is illustrated as follows.






\section{The Concept of Remote Indigenous Community Empowerment (RIC) Limitations to the Concept of Empowerment}

Parson, et.al., (1994), explains empowerment as a process in which people become strong enough to participate in sharing control over, and influence on events and institutions that affect their lives. Empowerment allows people to gain adequate skills, cooperation, knowledge, and power to change their lives and the lives of others. Ife (1995), argued that empowerment aims to increase the power of weak people. Furthermore, according to Ife (1995: 61-64), empowerment deals with two key notions; power and weak groups.

Based on the above view, empowerment is refers to both process and goal. As a process, empowerment is a series of activities that strengthens the power of weak groups in society, including individuals who experience poverty issues. As a goal, empowerment refers to the circumstances or results to be achieved through social changes; to create empowered community with adequate knowledge, physical, economic, and social confidence, ability to convey aspirations, welfare, and ability to participate in social activities, and independence in carrying out their activities. Empowerment as an objective is often used as an indicator to the success of empowerment as a process.

\section{Indicators of Empowerment}

According to Kieffer (1981), empowerment includes three dimensions including popular competence, sociopolitical competence, and participatory competence (Suharto, 1997: 215). Parsons et.al. (1994: 106) also proposed three dimensions of empowerment that include: (1) A development process that starts from individual growth which then develops into a greater social change. (2) A psychological state that is characterized by selfconfidence, usefulness, and ability to have control over themselves and others. (3) Liberation from a social movement, which starts from the education and politicization of the weak communities to gain power and positive changes in disadvantageous structures.

Schuler, Hashemi and Riley (in Suharto, 2005) have developed eight indicators of empowerment referred to as the empowerment index. The success of community empowerment can be seen from economic capacity, welfare, cultural and political abilities. These three aspects are related to four dimensions of power namely: 'power within', 'power for', 'power over', and 'power with'. Several indicators of empowerment include (1) Freedom of mobility; (2) Ability to buy small commodities; (3) Ability to buy large commodities; (4) Relative freedom from family domination; (5) Involvement in making household decisions; (6) Political and legal awareness; (7) Involvement in campaigns and protests; (8) Economic guarantees and family contributions.

\section{Remote Indigenous Community (RIC)}

Problems related to Remote Indigenous Communities (RIC) are social welfare problems in Indonesia that requires proper attention from all parties. The population of such community are still quite large, and they live in places that are difficult to access. Most of them also have less-advanced economic, social, and cultural conditions. However, they are citizens who have the equal obligations and rights to participate in national development.

RIC have distinct socio-cultural life. They usually share similar characteristics as small, closed and homogeneous communities in which social institutions are formed based on kinship, live in geographically- 
remote area and are relatively difficult to reach, live with subsistence economic systems, use simple equipment and technology, being dependent on the natural environment and they have limited access to social, economic and political services (Keppres No. 111/99).

\section{Empowerment Program for Remote Indigenous Communities}

In general, empowerment program for RIC is mainly related to the fulfilment of the their needs in various aspects of life and livelihood to be able to bring socio-cultural and environmental changes among the community. The objectives of RIC empowerment policy include; (1) Improving the professionalism of social services carried out by the government, community and business world towards RIC. (2) Improving equitable social services since each RIC have the right to obtain the best social services. (3) Strengthening the management of social services for RIC through continuous improvement in the planning, implementation, monitoring, evaluation and report of social services betterment in terms of quality and accountability. (4) Increasing and strengthening community social participation in social service by involving all elements and components of the society on the basis of self-reliance and social solidarity to form well-institutionalized and sustainable social welfare.

\section{RESEARCH METHOD}

This research was conducted using qualitative approach. The focuses of this research included; (1) Standards and policy objectives, (2) Implementation resources, (3) Communication between organizations and empowerment activities, (4) Characteristics of the implementing agencies, (5) Disposition of implementers, (6) Environmental social, economic and political conditions. This research took place in Maudemu Village, Lamaknen District, Belu Regency which selection of research location was done based on purposive technique (based on certain considerations) regarding the area that still suffered from constraints related to social welfare issues. The data obtained in this research included primary and secondary data which were collected through interviews, documentation and observation. The data of this research sourced from people, documents and events. The data were then analyzed based on Bogdan \& Biklen, (in Moleong, 2001: 9) which steps included; (1) Information gathering; (2) data reduction; (3) Confirmability Test; (4) Data presentation; (5) Conclusion or verification. The validity of the research data was confirmed through triangulation.

\section{Policy Standards and Targets}

\section{RESEARCH RESULTS AND DISCUSSIONS}

Measures and objectives of a policy are important in directing the implementation based on the plan. The RIC empowerment policy measure and target were the fulfilment of the needs in various aspects of life and livelihood of RIC in order to be able to respond to changes in social, cultural and environmental aspects.

Based on the results of the research, it was found that the RIC Empowerment Program in Maudemu Village, Belu Regency, NTT has met the standardized policy strategy based on the regulations and legal basis. The NTT Provincial Social Service as the leading sector has established 15 strategic steps to implement the RIC Empowerment Program in Maudemu Village, Belu Regency, NTT, including (1) Formation of a team for empowerment program preparation; (2) Initial assessment and feasibility study; (3) Preparation of community conditions; (4) Integrated social guidance and motivation; (5) RIC residents' social assistance; (6) Administration of de-concentration activities; (7) Preparation of RIC program; (8) Assistance for social settlement stimulants; (9) Provision of stimulant assistance for environmental facilities and infrastructure; (10) Provision of plant seed aids for RIC residents, (11) Provision of household equipment, (12) Provision of life insurance, (13) Provision of work equipment for RIC residents, (14) Implementation of monitoring activities of co-administration tasks, and (15) Implementation of administration co-administration activities.

The results of research on aspects of Standards and Policy Targets showed that in terms of aspects of policy standards and targets, the RIC Empowerment Program in Maudemu Village, Belu Regency, NTT, had referred to standard policies and standards, which are regulated in Permensos Number 9 of 2012, Chapter IV (articles 27, 28 and 29), and in Presidential Regulation Number 186/2014, concerning the Social Empowerment Program for Remote Indigenous Communities, which stipulates the standards and policy targets including: (1) life insurance consisting on food (food); (2) facilities and infrastructure consisting of residents' houses, worship place, clean water supply, household appliances etc. In addition, this program is also regulated in Presidential Regulation number 186/2014, which states that RIC program policy targets are include the fulfilment of basic needs, accessibility to services, health, education, information, population and government administration, work skills, maternal and child welfare.

Based on the research findings, it can be said that the standard implementation variables and policy targets actually have clear references including Permensos Number 9 of 2012, Chapter IV (articles 27, 28 and 29) and the Presidential Regulation Number 186/2014, regulating the Social Empowerment Program for Remote Indigenous Communities.

\section{The Resources for Policy Implementation}


In relation to policy implementation, it is found in this research that the preparation of the RIC empowerment program in the Maudemu Village actually involved human resources with measurable capabilities and had been. equipped with technical training through Technical Guidance (BimTek) activities and technical guidance. Such assistance was given in order to make sure that all actors understood their main tasks and functions on the field.

The results of this research also showed that a good synergy was established between the provincial, district and sub-district government in preparing technical officers during the briefing in the Technical Guidance (Bimtek) activities. Therefore, the human resources had met the predetermined quality. On the other hand, obstacles occurred related to the ability of RIC community as recipients. In general, they were inland people who have lived in rural areas for years (forests and mountains) that they had inadequate language ability and have obtained very limited information. This issue was a clear obstacle toward the efforts to achieve the target of the program. Language barrier often occurred, making it difficult to enhance the understanding of the community about the goal of the program that aimed to give them decent life. Cultural/custom-related issues also occurred as indigenous people tended to stick with their current lifestyle due to cultural reasons / customs that they believed in for long.

In addition, this research also showed that during the implementation of the program, inadequate financial resources in the form of technical funds was also a major obstacle that prevented the officers from providing routine assistance to the RIC community. The lack of tactical funds occurred due to the absence of other funding resources other than the one from the National Budget. The involvement of local governments both provincial and district governments through SKPD-SKPD failed to give financing interventions. Consequently, this issue made the performance less optima. Constraints faced by field officers were also related to the unavailability of additional fund for officers to be able to provide regular assistance and supervision. Remote areas that were difficult to reach required higher amount of technical budget for field officers to provide regular assistance. In addition, the lack of involvement of the private sector in providing financial support also indicated that the funding resources for this program were inadequate.

Based on the findings of the research, all officers involved in the implementation of this program had fairly good level of skills and comprehension as they had been equipped with Technical Guidance (Technical Guidance), and given guidance or technical instructions as well as trainings related to the implementation of the program in the field. Thus, they were able to carry out their respective roles according to the predetermined procedures and regulations. Meanwhile, in the aspect of Human Resources, ow level of education and lack of ability of the community to accept the program hindered the implementation of the program. The community showed certain behavior and cultural factors (local wisdom) that did not match the objectives of the program. This problem made the interaction process difficult.

Whereas, obstacles often occurred related to budget resources (capital / funding) which only came from the central ministry funds from the state budget. The lack of financial support from the local government caused a budget shortage, making it impossible to cover all the necessities of the community in Maudemu Village.

\section{Inter-Organization Communication and Activity Enhancement}

The success of a program is judged by the extent to which cooperation is established. In this context the cooperation referred to the communication and activity enhancement. Good communication would result in good coordination. Likewise, enhancement activities strengthened the unity, professionalism and cooperation that support the implementation of the program in the most effective way.

Research results showed that in the process of the program implementation, obstacles occurred regarding to communication between PRIC LWG at various levels and enhancement activities, especially in terms of funding. Consequently, a lot of activities done by field staffs were constrained / constrained by funding issues. Inadequate responses from agencies / SKPDs incorporated in the PRIC LWG impacted the program implementation. The synergy between Provincial Social Service agencies and PRIC LWG could not trigger positive response, resulting ineffective communication between institutions as program implementers. This problem certainly affects the work performance of institutions. Good cooperation that was supposed to be established from the beginning. It is found based on the results of interviews with research informants that only the Social Service agencies had high consistency in program implementation.

Some strategic obstacles were found to hamper the efforts to achieve the program. SKPD leaders who were members of the NTT Provincial PRIC Working Group Decree did not maintain good coordination and communication during program planning and did not give proper intervention towards the implementation of efforts to achieve RIC empowerment programs. In addition, it was also revealed that lack of coordination and technical fund issues were also factors that hindered good cross-sectoral coordination. Whereas, at the district level, tiered coordination and communication relations were not well-established. Thus, regional level implementers at the sub-district level became unable to perform adequate control over the program implementation 
In addition, the communication process developed by the program implementers in the field with the RIC community in Maudemu Village was also ineffective. It occurred due to the fact that some officers did not understand the local language used by the community. The community spoke in local languages such as Tetum, Bunak, Kemak, Marae and others. The relatively primitive community with strong local culture makes it difficult to maintain good communication between officers and local indigenous people.

\section{The Characteristics of the Implementing Agents}

Formal and informal organizations were involved in the policy implementation since it required right and suitable characteristics of the implementing agencies to guarantee the success of the program. Proper characteristics were necessary as the program dealt with different sectors. Democratic and persuasive implementing agents were needed. In addition, the scope or area is an important consideration in determining the appropriate policy implementing agents.

The implementation of RIC Empowerment program in Maudemu Village was carried out using a bottomup approach model, involving a number of implementing agencies both at the Provincial, Regency, Regency level, District and village as well as a university institutions. It indicated that the work procedures carried out by the implementing agencies have passed feasibility test to choose only democratic and persuasive agents that met the SOP.

The results of research showed that the determination of the location and the reporting mechanism involved institutions and government agencies as program implementers at various levels using the bottom up model approach. Hence, such involvement was possible to be carried out based on the characteristics of each policy implementing agent.

Based on the research findings, the implementation of the RIC empowerment program regarding the implementing agent characteristics was reflected by the formation of a Working Group (PRIC Working Group) consisting of various SKPDs at both the provincial and district levels and Higher Education institutions. NTT already had proper standardized policy strategy made based on regulations and legal basis including 15 strategic steps to implement RIC Empowerment Program in Maudemu Village Belu, NTT as follows. (1) Establishment of an implementation team for empowerment program preparation; (2) Initial assessment and feasibility study; (3) Preparation of community conditions; (4) Integrated social guidance and motivation; (5) RIC residents' social assistance; (6) Administration of de-concentration activities; (7) Preparation of RIC program; (8) Provision of assistance for social settlement stimulants; (9) Providing stimulant assistance for environmental facilities and infrastructure; (10 Provision of plant seed aids for RIC residents, (11) Provision of household equipment, (12) Provision of life insurance, (13) Provision of work equipment for RIC residents, (14) Implementation of monitoring activities of co-administration tasks, and (15) Implementation of Co-administration activities. However, several problems occurred during the process including inadequate responses from the SKPD involved in the NTT PRIC Working Group that made the coordination, consultation and communication less-effective. In addition, inadequate fund also had implementers to share the available amount with cross-sectional technical implementation of SKPD. Moreover, this problem was worsened by the absence of regulations that could enhance the cooperation between SKPDs.

\section{Implementers' Disposition}

Changes in economic, social and political conditions can affect the interpretation of the problem and thus will affect the way the a program is implemented. In addition, dynamic political situation also affects work performance. A change of government can result in changes in the way policies are implemented even without changing the policy itself. On the other hand, widespread and in-depth acceptance of policy standards and objectives is a great support for successful policy implementation (Kaufinan in Van Mater and Van Horn, 1975). Finally, the intensity of disposition of implementers can influence the implementation (performance) of the policy. Lack or limited intensity of this disposition can lead to the failure of policy implementation. Implementer disposition includes the response from implementer toward the policy and the will or initiative of the implementer to take part in running a program based on their own duties.

Based on the results of the study, implementing agents had shown a good response toward the RIC Empowerment program in the Maudemu Village. They perceived the program as the effort made by the central government in helping improve the welfare of the community, especially indigenous peoples in remote areas. They understood that the implementation of this program needed supports from various agencies, both government and other institutions. However, during the implementation, problems occurred and impacted the synergy between institutions as implementing actors, especially in terms of budgeting planning, resulting in poorly-implemented programs.

Inadequate responses from agencies that are members of the PRIC LWG both at the provincial and district levels indicated that tactical budget issue was the major obstacle that made the agencies unable to intervene the program.

Social, Economic and Political Conditions 
Changes in economic, social and political conditions can affect the interpretation of the problem and thus will affect the way a program is implemented and affect the work performance as well. A change of government can result in changes in the way policies are implemented without changing the policy itself.

In this research, it was found that the implementation of the program received positive support from the implementing agencies and the community as the target of the program. This indicates that the RIC Empowerment program in Maudemu Village received a positive response from residents as beneficiary social agents. Meanwhile, the Indigenous Community in Maudemu Village lived in remote areas and were in urgent need of assistance from this program. Regarding the information obtained from the field, socio-environmental support, economic and political views were in line with the program policies.

\section{CONCLUSIONS}

1. The main problems experienced by RIC residents in Maudemu Village, Belu Regency, East Nusa Tenggara were; (a) Limitations in meeting basic needs, including clothing, food and shelter; (b) Limitations in accessing various services provided by the government, including education, health, public administration, religious facilities and clean water services; (c) The low level of welfare of mothers and children.

2. The Remote Indigenous Community Empowerment Program in the Maudemu village of Lamaknen subdistrict could not meet the expected qualifications even though proper actions had been taken to bring about better changes, especially to improve the lives and welfare of the remote indigenous communities.

3. Empowerment program through the provision of consumptive social assistance and infrastructure (housing) support, life insurance assistance (staple food) plant seedlings, work equipment assistance, household equipment assistance has met the predetermined mechanisms. Those assistances have been distributed to the right target.

4. Ineffective implementation of the program was due to weak regional regulations, limited tactical funds or budget allocated for SKPDs incorporated in the PRIC LWG to establish the empowerment programs, and transportation issues, communication issues and weather-related problems.

\section{SUGGESTIONS}

1. Several fundamental problems were identified in the implementation of the empowerment program for RIC including problems related to (a) fulfilment of basic needs, (b) limited access to public services, and (c) mother and child welfare problems. Therefore, it is important to take those issues into consideration in determining the objectives of the empowerment program to improve the welfare of the remote indigenous community in Maudemu village.

2. Further evaluation is expected to be carried regarding the failure of the program in improving the community's economic condition. Therefore, it is expected that the planning and empowerment pattern are adjusted to participatory empowerment pattern to reach single perception between the government, community and stakeholders in analyzing the potential business sectors in the community such as proper changes in agriculture by providing superior seeds for greater production.

3. Concrete efforts need to be made by the government to improve the active participation (involvement) of various government agencies at the level of SKPD in provincial and district areas. Such efforts should be done to make planning, drafting, stipulation, funding, implementation and intervention and evaluation of the program become more systematical and integrated through positive and proactive cross-sectoral coordination, consultation and communication mechanisms between the central, provincial and district government.

\section{REFERENCES}

Anderson, James. (1979). Public Policy Making, (Second ed.). Ney York: Holt Renehart and Winston. Anderson, James E. (2003). Public Policy Making: An Introduction Fifth Edition. Boston: Houghton Mifflin Company.

Edward III, George C. (1980). Implementing Public Policy. Washington: Congressional Quarterly Press. Eyestone, Robert. (1971). The Treads of Public Policy: A Study in Policy Leadership. Indianapolis: BoobsMerrill.

Heinz, Eulau. and Kenneth Prewitt. (1973). Labyrinths Of Democrazy. Indianapolis: Boobs Merrill. 
Ife, Jim. (1995). Community Development: Creating Community Alternatives,Vision, Analysis and Practice. Australia: Longman.

Kieffer, C.H. (1981). The Emergence of Empowerment; The Development of Participatoru Co,petence Among Individuals in Citizen Organizations, Unpublished Ph. D. Disertation, University of Michigan, Ann Arbor.

Lasswell, Harold D and Kaplan, Abraham. (1970). Power and Society. New Haven: Yale University Press.

Mazmanian, Daniel A and Paul A. Sabatier. (1983). Implementation and Public Policy. USA: Scott Foresman and Company.

Moleong, Lexy J. (2001). Metodologi Penelitian Kualitatif. Bandung: Remaja Rosdakarya.

Nawawi, Ismail. (2009). Public Policy, Analisis,Strategi Advokasi Teori dan Praktek. Surabaya: PMN.

Parson, et. al. (1994). The Integration Of Social Work Practice. California: Wardworth.inc.

Pressman, J.L. and Wildavsky. (1973). Implementation. Barkley and Los Angeles: University of California Press.

Ripley, Randal B. (1985). Policy Analysis in Political Science. Chicago: Nelson-Hall Publisher.

Rose, Richard. (1969). The Power Elite. New York: Oxford University Press.

Subarsono, A. G. (2005). Analisis Kebijakan Publik Konsep, Teori dan Aplikasi. Yogyakarta: Pustaka Pelajar.

Subarsono, AG. (2006). Analisis Kebijakan Publik: Konsep Teori dan Aplikasi. Yogyakarta: Pustaka Pelajar.

Suharto, Edi. (1997). Pembangaunan Kebijaksanaan dan Pekerja Sosial Spectrum Pemikiran. Bandung: SPSTKS.

Suharto Edi, Ph,D. (2005). Membangun MasyaraRIC Memberdayakan Rakyat: kajian Strategis Pembangunan Kesejahteraan Sosial \& Pekerjaan Sosial. Bandung: Refika Aditama.

Sulaiman, Munandar. (1998). Dinamika MasyaraRIC Transisi. Yogyakarta : Pustaka Pelajar.

Titmuss. (1974). Social Policy. Jakarta: Handal Niaga Pustaka.

Van Meter, Donal dan Van Horn, Carl E. (1975). The Policy Implementation Process Conceptual Frame Work. Journal Administration and Society.

Widodo. (1974). Pengukuran Kerja. Yogyakarta: Balai Pembinaan Administrasi Universitas Gadjah Mada. 